\title{
Effect of different phosphorus sources applied with phosphate solubilizing bacteria on bio-geochemical properties and phosphorus release pattern in vertisol
}

\section{Vignesh}

Department of Soil Science and Agricultural Chemistry, Faculty of Agriculture, Annamalai University, Annamalainagar- 608002 (Tamil Nadu), India

\section{P. Senthilvalavan*}

Department of Soil Science and Agricultural Chemistry, Faculty of Agriculture, Annamalai University, Annamalainagar- 608002 (Tamil Nadu), India

\section{R. Manivannan}

Department of Soil Science and Agricultural Chemistry, Faculty of Agriculture, Annamalai University, Annamalainagar- 608002 (Tamil Nadu), India

\section{Ravikumar}

Department of Agronomy, Faculty of Agriculture, Annamalai University, Annamalainagar608002 (Tamil Nadu), India

${ }^{*}$ Corresponding author. Email: senvalavan_m2002@yahoo.co.in

\section{Article Info}

https://doi.org/10.31018/

jans.v13i2.2706

Received: April 28, 2021

Revised: June 3, 2021

Accepted: June 7, 2021

\section{How to Cite}

Vignesh, D. et al. (2021). Effect of different phosphorus sources applied with phosphate solubilizing bacteria on bio-geochemical properties and phosphorus release pattern in vertisol. Journal of Applied and Natural Science, 13(2), 715 - 722. https://doi.org/10.31018/jans.v13i2.2706

\begin{abstract}
Various phosphorus $(\mathrm{P})$ fertilizers are used for crop production in different types of soil. But there is a knowledge gap in choosing the right source and form of $P$ fertilizers to enhance the applied fertilizer use efficiency. An experiment was taken to identify the best phosphorus source and its effectiveness as a source of $P$ in vertisol to unravel this problem of selecting suitable $P$ fertilizer. With this background, an incubation experiment was conducted under laboratory condition to determine the phosphorus release pattern of different $P$ sources [Single Super Phosphate (SSP), Rock Phosphate (RP), Diammonium Phosphate (DAP), Nano phosphate (Nano P), Phosphocompost (PC)] applied with phosphate solubilizing bacteria (PSB) and their influence on biogeochemical properties in vertisol. Experimental results emphasized that $P$ release from different sources was influenced by soil $\mathrm{pH}$, electrical conductivity (EC), cation exchange capacity (CEC), soil organic carbon (SOC), and microbial population. Applied $\mathrm{P}$ sources significantly $(\mathrm{p}=0.05)$ influenced the $\mathrm{CEC}$, SOC, and microbial population except for soil $\mathrm{pH}$ and Ec. The maximum release in available $P$ was obtained at 30 and 60 days after incubation with SSP +PSB (35.8 and $\left.40.1 \mathrm{mg} \mathrm{kg}^{-1}\right)$ and Nano $\mathrm{P}+\mathrm{PSB}$ (33.9 and $38.6 \mathrm{mg} \mathrm{kg}^{-1}$ ) applied treatments, respectively. Whereas at 90 days after incubation Nano P + PSB (42.3 mg $\left.\mathrm{kg}^{-1}\right)$ and Phosphocompost + PSB $\left(40.4 \mathrm{mg} \mathrm{kg}^{-1}\right)$ treatments recorded the maximum $\mathrm{P}$ availability and minimum $\mathrm{P}(15.2,13.9$ and $11.8 \mathrm{mg} \mathrm{kg}^{-1}$ ) release was noticed in the control treatment throughout the period of incubation. It was evident that SSP or Nano $\mathrm{P}$ along with PSB application might be the best P source for Vertisol.
\end{abstract}

Keywords: Nano phosphate, Phosphocompost,Phosphorus release pattern PSB, Single super phosphate, Vertisol

\section{INTRODUCTION}

Phosphorus is an important nutrient that limits the yield of more than $40 \%$ of the world's arable land. World phosphorous $(P)$ reserve is getting depleted faster, and certain reports estimate that there will no soil $P$ reserve left by 2050 (Dey et al.,2017; Bhat et al.,2017). Further, $P$ fertilizers in India are more expensive as it is import- ed from other countries and due to high cost, only wealthy farmers can utilize for their crops. To liquefy this utility monopoly, farmers need possible low-cost alternatives, or they have to use fertilizers in suitable forms. Phosphorus $(P)$ is one of the major essential nutrient elements and the 10th most abundant element in the earth's crust, its complex chemistry in the soil makes it a highly deficient nutrient element in most of 
the arable soils across the world. Only $0.1 \%$ of the total $\mathrm{P}$ in the soil is available for uptake by plants (FAl, 2016) because of its fixation as various insoluble compounds depending upon the soil reaction. In the Indian context, about $49.3 \%$ of districts are reported to have low available P content based on 9.6 million soil test values (India Stat, 2018). Thus, the application of P-fertilizers to maintain soil fertility and sustain crop productivity becomes imperative in today's input-intensive agriculture. Therefore, research priorities aim to find alternative sources of P-fertilizers with the right source and form to use in various soils. Further, the applied $P$ fertilizers are in a huge problem of getting fixed in soil lattices its availability in soil solution will be very low. The solubilization of fixed $P$ should be done properly for enhancing the fertilizer use efficiency to increase the available $P$ in soil solution. At the same time,solubilization of fixed $P$ requires proton $(\mathrm{H}+)$, which can be obtained through chemical or microbial intervention. Organic acids are generally responsible for $\mathrm{P}$ solubilization various $\mathrm{P}$ solubilizers could enhance it without harming the environment. Further, the effectiveness of different fertilizers like conventional, nano-fertilizers, organic manures and composts in agriculture to improve soil moisture retention capacity, neutralizers, and improving plant growth has been assessed in several investigations (Singh et al.2017). Therefore, it is necessary to identifying the right source and form of $P$ fertilizers to assure its requirement in soil for better crop production and conserve $P$ sources for the future world. Thus, the present investigation was oriented to utilize different $P$ fertilizers along with a $P$ solubilizer on the $P$ release pattern and soil biogeochemical properties in vertisol.

\section{MATERIALS AND METHODS}

A bulk surface soil sample $(<20 \mathrm{~cm}$ depth) from the farmer's field, which was identified after surveying available $\mathrm{P}$ content at BhuvanagiriMutlur village, Chidambaram Taluk in Cuddalore District, Tamil Nadu, India, was collected to study the phosphorus release pattern of different P sources applied with PSB and its effect on physico-chemical and biological properties of soil. The soil was air dried and sieved through $2 \mathrm{~mm}$ sieve prior to use in the experiment. One kilogram of $2 \mathrm{~mm}$ sieved soil was filled in plastic containers. After that, calculated quantities of fertilizers and organics (w/w basis) were added as per treatments and mixed well. A completely randomized design was used with of seven treatments (six treated (PSB alone, SSP + PSB, RP +PSB, DAP + PSB), Nano P + PSB, Phosphocompost (water hyacinth based) + PSB and one absolute control) with three replications and maintained for 3 months ( 90 days) at room temperature(Table 1). Thus, seven treatment combinations were set aside in 21 containers separately and maintained the soil moisture at about 60 per cent of the field capacity. The moisture level was maintained by adding water daily to compensate the loss due to evaporation. Soil samples were drawn at 30 days interval (30, 60 and $90 \mathrm{DAl})$ and dried under shade used for analysis of soil organic carbon content (Chromic acid wet digestion method), pH, EC, CEC (Neutral normal ammonium acetate method) and available $P$ [Olsen method- Ascorbic acid method using Spectrophotometer $(660 \mathrm{~nm})]$ and microbial population(standard serial dilution plating technique of Pramer and Schemidt (1965).This incubation experiment was conducted in the Department of Soil Science and Agricultural Chemistry, Faculty of Agriculture, Annamalai University, Annamalainagar, from October-December 2017.Soil classified as clayey texture soil with $54.6 \%$ water holding capacity. Typic haplusterts having slightly saline $\mathrm{pH}$ of $7.4\left(1.2 .5\right.$,soil:water), electrical conductivity $\left(0.51 \mathrm{dSm}^{-1}\right.$ at $25^{\circ} \mathrm{C}$ ), low $\mathrm{KMnO}_{4}$ extractable- $\mathrm{N}\left(194 \mathrm{~kg} \mathrm{ha}^{-1}\right)$, medium in $\mathrm{NaHCO}_{3}-\mathrm{P}\left(17.4 \mathrm{~kg}\right.$ ha $\left.{ }^{-1}\right)$, medium in $\mathrm{NH}_{4} \mathrm{OAc}-$ extractable $\left(152 \mathrm{~kg} \mathrm{ha}^{-1}\right)$ and 0.61 percent soil organic carbon content.

\section{Statistical analysis}

The data of heavy metal concentrations and soil properties of different amendments were subjected to oneway analysis of variance (ANOVA). All the statistical tests were performed using SPSS software. The significant differences between the means were tested against the critical difference at $5 \%$ probability level.

\section{RESULTS}

\section{Effect of $P$ sources and PSB on bio-geochemical properties}

An incubation experiment was tried out to unravel certain confounding characteristics of phosphorus release in soil having clay texture with respect to the $P$ sources plus PSB along with NK $100 \%$ RDF added for changing its solubility and availability and changes in biogeochemical properties, and the results are given in table 2 and 3 .

\section{Microbial population (Bacteria, fungi and actinomycetes)}

The total microbial loads at 30,60 and 90 DAl showed a varying trend in all the treatments (Table 3 ). The microbial population was (Bacteria $\times 10^{6} \mathrm{CFU} \mathrm{g}{ }^{-1}$, fungi $x$ $10^{3} \mathrm{CFU} \mathrm{g}^{-1}$, actinomycetes $\times 10^{4} \mathrm{CFU} \mathrm{g}^{-1}$ ) significantly influenced by the addition of $\mathrm{P}$ sources and PSB. Addition of NK100\% RDF + Phosphocompost + PSB $\left(T_{7}\right)$ found to be superior by registering higher microbial population of $51,72,89 ; 17,21,21$ and $30,38,37$ at $30,60,90 \mathrm{DAl}$, respectively and it was on par with $T_{6}$ and $T_{6}$ followed by $T_{4}, T_{5}, T_{3}, T_{2}$, and $T_{1}$ (Absolute control), which registered the lower microbial population $(28,49,60 ; 7,12,14$ and $18,22,24)$ at all the stages of 
Vignesh, D. et al. / J. Appl. \& Nat. Sci. 13(2), 715 - 722 (2021)

Table 1. Treatment details and statistical design used in the experiment.

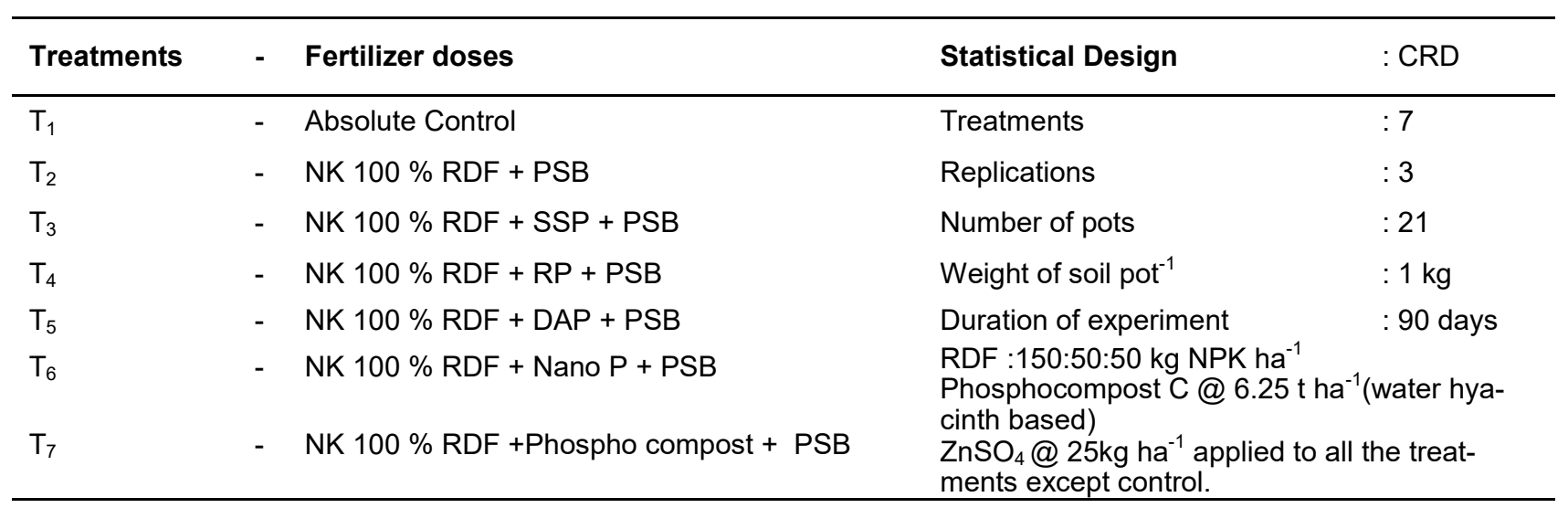

incubation, respectively.

\section{Soil pH}

The $\mathrm{pH}$ values recorded at 30,60 and 90 days after incubation (DAl) ranging from 7.32 to $7.62,7.31$ to 7.62 and 7.28 to 7.61 , respectively (Table 2 ). The results were statistically non-significant. However, higher $\mathrm{pH}$ values of $7.62,7.62$ and 7.61 were recorded in absolute control $\left(\mathrm{T}_{1}\right)$ and lower $\mathrm{pH}$ values of $7.32,7.29$ and 7.28 were recorded in NK $100 \% \mathrm{RDF}+\mathrm{SSP}+\mathrm{PSB}$ $\left(\mathrm{T}_{3}\right)$ applied treatment at all the three stages of incubation, respectively.

\section{Electrical conductivity (EC)}

Treatments implemented in the experiment were not influenced the electrical conductivity of soil(Table 2). The EC values recorded were ranging from 0.46 to $0.47,0.45$ to 0.49 and 0.43 to $0.49 \mathrm{dSm}^{-1}$ at 30,60 and 90 days after incubation (DAI), respectively .

\section{Cation exchange capacity (CEC)}

The application of various $P$ sources plus $P S B$ along with a recommended dose of $\mathrm{N}$ and $\mathrm{K}$ fertilizers significantly machinates the CEC(Table 2).. Values of CEC obtained at 30, 60 and 90 days after incubation (DAI), ranging from 12.4 to $15.6,12.2$ to 15.7 and 12.2 to 16.1 $\left(\mathrm{C} \mathrm{mol}\left(\mathrm{p}^{+}\right) \mathrm{Kg}^{-1}\right)$, respectively. The highest CEC values of 15.6, 15.7 and $16.1\left(\mathrm{C} \mathrm{mol}\left(\mathrm{p}^{+}\right) \mathrm{Kg}^{-1}\right)$ were recorded inNK100\% RDF + Phosphocompost + PSB $\left(T_{7}\right)$, which was on par with the treatment $\mathrm{T}_{6}(\mathrm{NK} 100 \%$ RDF + Nano P+ PSB) followed by $T_{3}, T_{5}, T_{4}$ and $T_{2}$ at $30 \mathrm{DAI}$. Whereas at 60 and $90 \mathrm{DAl}$ higher CEC values of 15.7 and $16.1\left(\mathrm{C} \mathrm{mol}\left(\mathrm{p}^{+}\right) \mathrm{Kg}^{-1}\right)$ obtained in $\left(\mathrm{T}_{7}\right)$ followed by $T_{6}, T_{3}, T_{5}$ and $T_{4}, T_{2}$ (on par with each other), respectively. Further, the lowest CEC values of 12.4, 12.2 and $12.0\left(\mathrm{C} \mathrm{mol}\left(\mathrm{p}^{+}\right) \mathrm{Kg}^{-1}\right)$ were recorded by absolute control $\left(T_{1}\right)$ at all three stages of incubation, respectively.

\section{Soil organic carbon (SOC)}

The data associated to soil organic content was analyzed during the incubation experiment at 30,60 and 90 DAI (Table 2). SOC content was significantly $(p=0.05)$ influenced by various $P$ sources and the values ranging from 0.24 to 0.69 at $30 \mathrm{DAl}, 0.21$ to 0.68 at $60 \mathrm{DAl}$ and 0.18 to $0.71 \%$ at 90 DAI. Application of NK100 \% RDF + Phosphocompost + PSB $\left(\mathrm{T}_{7}\right)$ registered higher SOC of $0.69,0.68$ and $0.71 \%$ at all the stages of incubation and the treatments followed it in the order of $\mathrm{T}_{6}, \mathrm{~T}_{3}$ and $\mathrm{T}_{5} \mathrm{~T}_{4}$ (on par with each other) and $\mathrm{T}_{2}$, respectively. Absolute control treatment $\left(T_{1}\right)$ registered the lower values soil organic carbon content of $0.24,0.21$ and 0.18 $\%$ at 30,60 and $90 \mathrm{DAl}$, respectively.

\section{Effect on Olsen $P$ acquisition}

Effect of $\mathrm{P}$ and PSB sources on Olsen $\mathrm{P}$ content in soil observed at 30, 60 and $90 \mathrm{DAl}$ (Table 3).Significantly higher Olsen $\mathrm{P}$ content in soil was recorded in the treatment $\left(\mathrm{T}_{3}\right) \mathrm{NK} 100 \% \mathrm{RDF}+\mathrm{SSP}+\mathrm{PSB}$ (35.8 and $40.1 \mathrm{mg} \mathrm{kg}^{-1}$ ) which was on par with $\left(\mathrm{T}_{6}\right)$ NK100\% RDF + Nano P + PSB (33.9 and $38.6 \mathrm{mg} \mathrm{kg}^{-1}$ ) at 30 and $60 \mathrm{DAl}$. These treatments were followed by $\mathrm{T}_{7}, \mathrm{~T}_{5}, \mathrm{~T}_{4}$ and $\mathrm{T}_{2}$ (significantly different). Whereas at 90 DAl the application of NK100\% RDF + Nano P + PSB $\left(T_{6}\right)$ registered higher $P$ content in soil $\left(42.3 \mathrm{mg} \mathrm{kg}^{-1}\right)$ which was on par with treatment $\left(\mathrm{T}_{7}\right)$ i.e. NK $100 \%$ RDF + Phosphocompost + PSB (40.4 mg kg-1). This was followed by $T_{3}, T_{5}, T_{4}$ (on par with each other) and $T_{2}$.Whilst, the lowest values of Olsen $P$ content $\left(15.2,13.9\right.$ and $\left.11.8 \mathrm{mg} \mathrm{kg}^{-1}\right)$ were observed in the absolute control treatment $\left(T_{1}\right)$ at 30,60 and $90 \mathrm{DAI}$, respectively.

\section{DISCUSSION}

Effect of different phosphorus sources combined with PSB on bio-geochemical properties and release pattern of $P$ in vertisol

\section{Soil biogeochemical properties}

The present study observed that bio-geochemical properties viz., $\mathrm{pH}, \mathrm{EC}, \mathrm{CEC}, \mathrm{SOC}$, microbial population (bacteria, fungi, actinomycetes) and Olsen $\mathrm{P}$ had $\mathrm{a}$ varying trend on its values due to the addition of various P sources plus PSB along with NK $100 \%$ RDF 
fertilizers at 30,60 and $90 \mathrm{DAI}$.

\section{Soil microbial population}

About the microbial population of incubated soil, the various $P$ sources and PSB applied treatments significantly influenced the microbial biomass at 30,60, and $90 \mathrm{DAl}$ (Table 3). The higher microbial biomass (soil bacteria, fungi, and actinomycetes) observed in NK 100 $\%$ RDF + Phosphocompost +PSB $\left(\mathrm{T}_{7}\right)$ followed by NK $100 \%$ RDF + Nano P + PSB $\left(\mathrm{T}_{6}\right)$ applied treatments at all the stages of incubation. This might be ascribed due to the addition of organic and inorganic fertilizers, which may affect the population, composition, and function of soil microorganisms. Inorganic fertilizers had relatively less effect on soil microbial biomass and activities than organics and bio-fertilizers. Further, this higher population of soil bacteria, fungi, and actinomycetes attributed higher organic carbon content duly by addition of phosphocompost plus PSB. Present study results are in line with those of Marschner et al.,2003; Amitava et al., 2008; Chesti et al.(2015),they opined that soil microbial community structure was affected by addition of organic amendments, composted water hyacinth material could serve as quality manure for improving soil health and manurial application attributes direct addition $\mathrm{OC}$ content to soil which stimulate growth and activity of microorganisms, respectively.

Further, Zhao et al. (2010) reported a close relationship between microorganism growth and activity to organic matter content in the soil. This provides carbon and energy sources for the growth of microorganisms. Lower microbial populations were recorded by NK100\% RDF + PSB $\left(T_{2}\right)$ and absolute control $\left(T_{1}\right)$ treatments. This might be caused by induced $\mathrm{pH}$ (variable charge) that may not favorable for microbial growth. This is in confirmation with the findings of Kang et al. (2005) who proved that the use of either chemical or organic fertilizers of insufficient levels resulted in poor soil microbial index.

\section{Soil reaction $(\mathrm{pH})$}

According to the ANOVA test, the application of $P$ sources plus PSB did not show any statistical significance on soil reaction $(\mathrm{pH})$. However, the soil $\mathrm{pH}$ was altered (increased or decreased) by the treatments when compared to the initial soil $\mathrm{pH}$ level (7.45) at all stages of incubation. The $\mathrm{pH}$ values in different treatments tried in the experiment at different stages (30, 60 , and $90 \mathrm{DAl}$ ) ranged from7.32 to $7.62,7.31$ to 7.62 and 7.28 to 7.61 , respectively. Decreased $\mathrm{pH}$ values were noticed in the treatments NK $100 \%$ RDF + SSP + $\mathrm{PSB}\left(\mathrm{T}_{3}\right), \mathrm{NK} 100 \% \mathrm{RDF}+\mathrm{Nano} \mathrm{P}+\mathrm{PSB}\left(\mathrm{T}_{6}\right)$ and NK $100 \%$ RDF + Phosphocompost + PSB $\left(T_{7}\right)$, whereas all other treatments showed a trend of increased $\mathrm{pH}$ values from 30 to 90 days of incubation ( Fig.1A). The lower soil $\mathrm{pH}$ values were observed in the treatments
NK $100 \%$ RDF + SSP + PSB $\left(\mathrm{T}_{3}\right)$, NK $100 \%$ RDF + Nano P + PSB $\left(\mathrm{T}_{6}\right)$ and NK $100 \%$ RDF + Phosphocompost + PSB $\left(\mathrm{T}_{7}\right)$ at all the stages of incubation experiment. This may be attributed due to the changes in electrochemical properties of soil through the added $P$ sources and PSB. P solubilizers owing to the release of low molecular weight organic acids like citric, oxalic, malic etc., during the course of microbial degradation have a positive influence on the soil reaction reported by Mandal (2014) ; Mandal et al., (2015). Also, a decrease or increase in $\mathrm{pH}$ over the period of both aerobic and anaerobic incubation in this study may be ascribed to the process of $\mathrm{H}^{+}$consumption or shift in the $\mathrm{H}^{+} / \mathrm{OH}^{-}$ during soil reduction or oxidation influenced by microbes. However, changes in soil $\mathrm{pH}$ were slightly altered due to the low dissociation constant of low molecular weight organic acids contributing low proton activity in soil solution. The activity of $\mathrm{P}$ solubilizing bacteria might be very meagre in the treatments, which in turn increased soil $\mathrm{pH}$ throughout the incubation period. Further, an increased level in $\mathrm{pH}$ was observed in the absolute control treatment $\left(T_{1}\right)$ might be attributed due to little or no availability of microbial activities to produce acidity. These findings confirm with those of Katkar et al. (2011) and Kannan et al. (2013), whose results evidenced that integrated fertilizers application has a positive significant correlation with physico-chemical and biological parameters compared to unfertilized treatments in Vertisol.

\section{Electrical conductivity $\left(\mathrm{dSm}^{-1}\right)$}

Considering the electrical conductivity (EC), according to the ANOVA test, the application of $P$ sources plus PSB did not show any statistical significance like soil $\mathrm{pH}$. The electrical conductivity of incubated soil decreased with the incubation period in all treatments. The EC values in different treatments at different stages $(30,60$ and $90 \mathrm{DAI})$ ranged from 0.46 to $0.47,0.45$ to 0.49 and 0.43 to $0.49 \mathrm{dSm}^{-1}$ at 30,60 and 90 days after incubation (DAI), respectively .However, slightly higher EC values were observed in absolute control $\left(T_{1}\right)$ at all the experiment stages. This may be attributed to the changes in electrochemical properties of soil without the addition of PSB. Microbes generally added organic acids during their degradation to soils for solubilizing nutrients (Fazli et al.,2016), and solubilization has a positive direct relation with $\mathrm{EC}$, which may be absent without PSB i.e. cationic solubilizing processes (reduction of $\mathrm{Ca}^{++}$concentration in soil) solution by microbes may be less or nil. By increasing, divalent calcium radicals or ions (salts) content in soil solution would cause the EC as increased. Further, the addition of inorganic fertilizers and biofertilizers might have swung the soil's electrical conductivity. In addition to that, the biogeochemical processes in soil and functions of added nutrient sources on soil reaction coupled with other 
soil physicochemical characteristics increase the EC of the soil solution. The study results are in line with Dushyant et al.(2015), who reported that application of $100 \%$ RDF through inorganic form had experienced higher $\mathrm{pH}$ and $\mathrm{EC}$ values when compered to integrated nutrient management treatments.

\section{Cation exchange capacity ( $\left.\mathrm{C} \mathrm{mol}\left(\mathrm{p}^{+}\right) \mathbf{~ k g}^{-1}\right)$}

Cation exchange capacity (CEC) is the direct measure of the quantum of negative charges in soil. Colloidal fractions in soil due to higher specific surface area and charge (dominantly under normal $\mathrm{pH}$ ) contribute largely to the soil's cation exchange capacity. Application of $P$ sources plus PSB significantly influenced the cation exchange capacity of experimental incubation soil. The CEC was altered (increased or decreased) by the treatments when compared to the initial soil CEC level (13.04 C mol $\left.(p+) \mathrm{kg}^{-1}\right)$ at all stages of incubation. The CEC values in different treatments at different stages (30, 60 and $90 \mathrm{DAl})$ ranged from 12.4 to $15.6,12.2$ to 15.7 and 12.2 to $16.1\left(\mathrm{C} \mathrm{mol}(\mathrm{p}+) \mathrm{Kg}^{-1}\right)$, respectively. Increased CEC values were noticed in all the treatments except absolute control $\left(\mathrm{T}_{1}\right)$. The Highest CEC values were observed in NK $100 \%$ RDF + Phosphocompost + PSB $\left(\mathrm{T}_{7}\right)$ and NK $100 \% \mathrm{RDF}+$ Nano P + PSB $\left(T_{6}\right)$ applied treatment at all the stages of incubation experiment may be due to charge contribution upon dissociation of low molecular weight organic acids. In general, higher CEC observed in Vertisol is due to the increased number of net negative charges on soil colloids with the increase in finer fraction (Hazalton and Murphy, 2007; Wei et al.,2010). Also, PSB addition might have stimulated the soil biological activity, which consequently increases the organic matter content and negative charges on the soil surface, thereby increasing exchangeable cations. Present results conform with those of (Alamgir et al., 2011). Whereas the lowest CEC was observed in the absolute control treatment $\left(T_{1}\right)$. This may be attributed to no molecular and or bio-fertilizers supplied to it, increasing the $\mathrm{pH}$, where sources of negative charges in the adsorbent site would be reduced by soil aggregation, thus decreasing the CEC.

\section{Soil organic carbon (\%)}

SOC is an important soil chemical property that decides the fertility of the soil. It gives an indirect indication of nutrient status in soil. Application of $P$ sources plus PSB significantly influenced the soil organic carbon content. The SOC values in different treatments at different stages $(30,60$ and $90 \mathrm{DAl})$ ranged from 0.24 to $0.69,0.21$ to 0.68 and 0.18 to $0.71 \%$, respectively. Increased SOC values were noticed in all the treatments except $\left(T_{2}\right)$ and $\left(T_{1}\right)$ treatments (Fig.2). Higher SOC (\%) values were observed in NK $100 \%$ RDF + Phosphocompost + PSB $\left(T_{7}\right)$ applied treatment at all the stages of incubation experiment compared to other
$P$ sources plus PSB tried. (Table 2 and Fig. 2). This addition of organic carbon might be due to the accumulation of plant residual lignin in water hyacinth enriched compost, directly flowing to the structural and metabolic soil carbon pool, and increased biologically active soil organic carbon such as microbial biomass carbon mineralizable carbon in the present experiment. Further, the non-labile or residual SOC fraction constitutes the percentage of SOC under integrated application of molecular and biofertilizers potentially increased SOC. The present study results conform with those of Dushyant et al. (2015); Aditya Kumar et al.(2018). Furthermore, it is confirmed with a linear relationship between CEC and SOC at 30, 60, 90 DAI. $\left(Y=6.244 x+10.58, R^{2}=0.702\right.$, $\mathrm{Y}=6.408 \mathrm{x}+10.57, \mathrm{R}^{2}=0.753, \mathrm{Y}=6.413 \mathrm{x}+10.50, \mathrm{R}^{2}=$ $0.707)$, respectively. Whereas the absolute control treatment $\left(T_{1}\right)$ received nothing and thus did not influence the carbon pool. Organic manure was the most effective in increasing SOC when compared with or without molecular fertilizers or other soil amendments. The $\mathrm{N}$ and $\mathrm{P}$ fertilization through organic manures stimulates microbial activity. It enhances $\mathrm{C}$ turnover (Thakur et al., 2011), which explains the negative values of $\mathrm{C}$ stabilization in the nutrient sources applied plots which were hindered or nil in the absolute control treatment.

\section{$\mathrm{P}$ release pattern (Available P-Olsen's) $\left(\mathrm{mg} \mathrm{kg}^{-1}\right)$ :}

Soil available $P$ increased with increasing $P$ application due to the increase in water-soluble $P$ in the soil. The quantity of the $P$ available in soil solution decides by the physical, biological, and chemical attributes of soil. In the present study, various phosphorus sources combined with $\mathrm{P}$ solubilizing bacteria applied were entirely and significantly differed, especially in soil chemical environments (Fig.1B). Olsen $P$ content ranged from 15.2 to $35.8 \mathrm{mg} \mathrm{kg}^{-1}$ at $30 \mathrm{DAl}, 13.9$ to $40.1 \mathrm{mg} \mathrm{kg}^{-1}$ at $60 \mathrm{DAl}$ and 11.8 to $42.3 \mathrm{mg} \mathrm{kg}^{-1}$ at $90 \mathrm{DAl}$. The maximum available $\mathrm{P}$ observed at $90 \mathrm{DAl}$ and the minimum values were at $30 \mathrm{DAl}$. Application of NK $100 \%$ RDF + SSP + PSB $\left(\mathrm{T}_{3}\right)$ clearly showed higher availability at 30 and $60 \mathrm{DAl}$ and it was comparable with NK $100 \% \mathrm{RDF}$ +Nano P + PSB $\left(\mathrm{T}_{6}\right)$ treatment. Whereas at $90 \mathrm{DAl}$ the application of NK $100 \%$ RDF + Nano P + PSB (T6) registered higher Olsen $P$ content which was on par with treatment $\left(\mathrm{T}_{7}\right)$ i.e. NK $100 \% \mathrm{RDF}+$ phosphocompost + PSB (Table 3 and Fig. 1B). Soil available $P$ clearly showed that PSB inoculation could have solubilized more $P$ from the soil than un-inoculated with $P S B$ or treatment without $P$ fertilizers. PSB might have helped in increasing the availability of insoluble $P$ in the soil pool. Further, the addition of $\mathrm{P}$ solubilizers stimulated the growth and activities of microorganisms, which increased $\mathrm{N}$ and $\mathrm{P}$ release. The effect was further enhanced by the addition of inorganic or organic fertilizers that are aptly available at different durations. These 
Vignesh, D. et al. / J. Appl. \& Nat. Sci. 13(2), 715 - 722 (2021)

Table 2. Effect of phosphorus sources and PSB on soil $\mathrm{pH}, \mathrm{EC}\left(\mathrm{dS} \mathrm{m} \mathrm{m}^{-1}\right)$, CEC $\left(\mathrm{C} \mathrm{mol}\left(\mathrm{p}^{+}\right) \mathrm{Kg}^{-1}\right)$ and soil organic carbon content $(\%)$.

\begin{tabular}{|c|c|c|c|c|c|c|c|c|c|c|c|c|}
\hline \multirow{2}{*}{$\begin{array}{l}\text { Days of Incubation } \\
\text { Treatments I } \\
\text { Parameters }\end{array}$} & \multicolumn{4}{|c|}{$30 \mathrm{DAI}$} & \multicolumn{4}{|c|}{$60 \mathrm{DAl}$} & \multicolumn{4}{|c|}{$90 \mathrm{DAl}$} \\
\hline & $\mathrm{pH}$ & EC & CEC & soc & $\mathrm{pH}$ & EC & CEC & soc & pH & EC & CEC & soc \\
\hline $\mathrm{T}_{1}$ - Absolute Control & 7.62 & 0.48 & 12.4 & 0.24 & 7.62 & 0.49 & 12.2 & 0.21 & 7.61 & 0.49 & 12.0 & 0.18 \\
\hline $\mathrm{T}_{2}-\mathrm{NK} 100 \% \mathrm{RDF}+\mathrm{PSB}$ & 7.52 & 0.47 & 13.2 & 0.59 & 7.53 & 0.48 & 13.3 & 0.58 & 7.50 & 0.48 & 13.1 & 0.60 \\
\hline $\mathrm{T}_{3}-\mathrm{NK} 100 \% \mathrm{RDF}+\mathrm{SSP}$ & 7.32 & 0.46 & 14.7 & 0.65 & 7.29 & 0.45 & 14.9 & 0.64 & 7.28 & 0.43 & 14.6 & 0.67 \\
\hline $\mathrm{T}_{4}-\mathrm{NK} 100 \% \mathrm{RDF}+\mathrm{RP}$ & 7.49 & 0.48 & 14.1 & 0.62 & 7.43 & 0.47 & 14.1 & 0.61 & 7.45 & 0.47 & 14.2 & 0.63 \\
\hline $\mathrm{T}_{5}-\mathrm{NK} 100 \%$ RDF + & 7.46 & 0.48 & 14.2 & 0.63 & 7.45 & 0.47 & 14.2 & 0.62 & 7.45 & 0.47 & 14.3 & 0.63 \\
\hline $\mathrm{T}_{6}-\mathrm{NK} 100 \% \mathrm{RDF}+$ & 7.35 & 0.46 & 15.5 & 0.68 & 7.31 & 0.45 & 15.3 & 0.67 & 7.30 & 0.44 & 15.6 & 0.69 \\
\hline $\begin{array}{l}\mathrm{T}_{7}-\mathrm{NK} 100 \% \mathrm{RDF}+ \\
\text { Phosphocompost + PSB }\end{array}$ & 7.42 & 0.47 & 15.6 & 0.69 & 7.40 & 0.46 & 15.7 & 0.68 & 7.38 & 0.45 & 16.1 & 0.71 \\
\hline SEd \pm & 0.25 & 0.013 & 0.178 & 0.007 & 0.24 & 0.014 & 0.18 & 0.006 & 0.25 & 0.013 & 0.20 & 0.007 \\
\hline$C D(P=0.05)$ & NS & NS & 0.374 & 0.015 & NS & NS & 0.387 & 0.014 & NS & NS & 0.41 & 0.015 \\
\hline
\end{tabular}

Table 3. Effect of $P$ sources and PSB on soil microbial population and Olsen $P(\mathrm{mg} / \mathrm{kg})$.

\begin{tabular}{|c|c|c|c|c|c|c|c|c|c|c|c|c|}
\hline \multirow{2}{*}{$\begin{array}{l}\text { Parameters } \\
\begin{array}{l}\text { Treatments / Days of } \\
\text { Incubation }\end{array}\end{array}$} & \multicolumn{3}{|c|}{$\begin{array}{l}\text { Bacteria (CFU/g } \\
\left.\text { soil } \times 10^{6}\right)\end{array}$} & \multicolumn{3}{|c|}{$\begin{array}{l}\text { Fungi (CFU/g } \\
\text { soil } \times 10^{3} \text { ) }\end{array}$} & \multicolumn{3}{|c|}{$\begin{array}{l}\text { Actinomycetes } \\
\left(\text { CFU/g soil } \times 10^{4}\right)\end{array}$} & \multicolumn{3}{|c|}{ Olsen $P\left(\mathrm{mg} \mathrm{kg}^{-1}\right)$} \\
\hline & $\begin{array}{l}30 \\
\text { DAI }\end{array}$ & $\begin{array}{l}60 \\
\text { DAI }\end{array}$ & $\begin{array}{l}90 \\
\text { DAI }\end{array}$ & $\begin{array}{l}30 \\
\text { DAI }\end{array}$ & $\begin{array}{l}60 \\
\text { DAI }\end{array}$ & $\begin{array}{l}90 \\
\text { DAI }\end{array}$ & $\begin{array}{l}30 \\
\text { DAI }\end{array}$ & $\begin{array}{l}60 \\
\text { DAI }\end{array}$ & $\begin{array}{l}90 \\
\text { DAl }\end{array}$ & $\begin{array}{l}30 \\
\text { DAI }\end{array}$ & $\begin{array}{l}60 \\
\text { DAI }\end{array}$ & $\begin{array}{l}90 \\
\text { DAI }\end{array}$ \\
\hline $\mathrm{T}_{1}$ & 28 & 49 & 60 & 15.2 & 13.9 & 11.8 & 7 & 12 & 14 & 15.2 & 13.9 & 11.8 \\
\hline $\mathrm{T}_{2}$ & 31 & 54 & 65 & 24.3 & 25.1 & 26.0 & 9 & 14 & 16 & 24.3 & 25.1 & 26.0 \\
\hline $\mathrm{T}_{3}$ & 37 & 59 & 80 & 35.8 & 40.1 & 37.1 & 11 & 21 & 24 & 35.8 & 40.1 & 37.1 \\
\hline $\mathrm{T}_{4}$ & 44 & 65 & 75 & 27.9 & 29.4 & 31.0 & 16 & 19 & 18 & 27.9 & 29.4 & 31.0 \\
\hline $\mathrm{T}_{5}$ & 40 & 61 & 72 & 28.1 & 32.1 & 33.9 & 12 & 17 & 19 & 28.1 & 32.1 & 33.9 \\
\hline $\mathrm{T}_{6}$ & 48 & 69 & 86 & 33.9 & 38.6 & 42.3 & 16 & 19 & 23 & 33.9 & 38.6 & 42.3 \\
\hline $\mathrm{T}_{7}$ & 51 & 72 & 89 & 31.1 & 35.2 & 40.4 & 17 & 21 & 21 & 31.1 & 35.2 & 40.4 \\
\hline SEd \pm & 1.79 & 1.85 & 2.01 & 1.21 & 1.36 & 1.43 & 0.94 & 0.89 & 0.91 & 1.21 & 1.36 & 1.43 \\
\hline$C D(P=0.05)$ & 3.77 & 3.89 & 4.23 & 2.59 & 2.92 & 3.07 & 1.98 & 1.87 & 1.92 & 2.59 & 2.92 & 3.07 \\
\hline
\end{tabular}

results are in corroboration with those of Pandey et al. (2010); Panhwar et al., 2011; Panhwar et al., 2013:Yan et al., 2017). They opined that microbes harbouring in soil with or without crop rhizosphere provide better nutrient availability or solubilizing insoluble forms of nutrients and play a key role in organic matter decomposition, nutrient cycling, and other chemical transformations in soil. Further, a significant difference in the availability of $P$ at different incubation periods showed the efficiency of applied $P$ fertilizers. For example, OIsen $P$ availability was higher with SSP + PSB followed by Nano P + PSB applied treatments at 30 and 60 DAl. But at 90 DAI Nano $P$ applied treatments showed higher $P$ availability and it was on par with Phosphocompost + PSB applied one. These results evidently proved that phosphorus availability in soil not only relied upon source but also with the form of fertilizers applied i.e. Molecular P fertilizer like SSP, DAP, etc or Nano P fertilizers or composts enriched with molecular fertilizers or Nano fertilizers. But it will be a big question in making $P$ availability in soil solution for a longer duration with less $P$ fixation under aerobic or anaerobic soil environment. However, the present study results conform the findings of Sharmila Rahale (2011), Kannan et al., 2012), Tarafdar et al. (2012c), and Selva Preetha and Balakrishnan (2017).

\section{Conclusion}

In this study, among the different $P$ sources, the available $P$ increased significantly due to the application of different $P$ fertilizers compared with the control treat- 


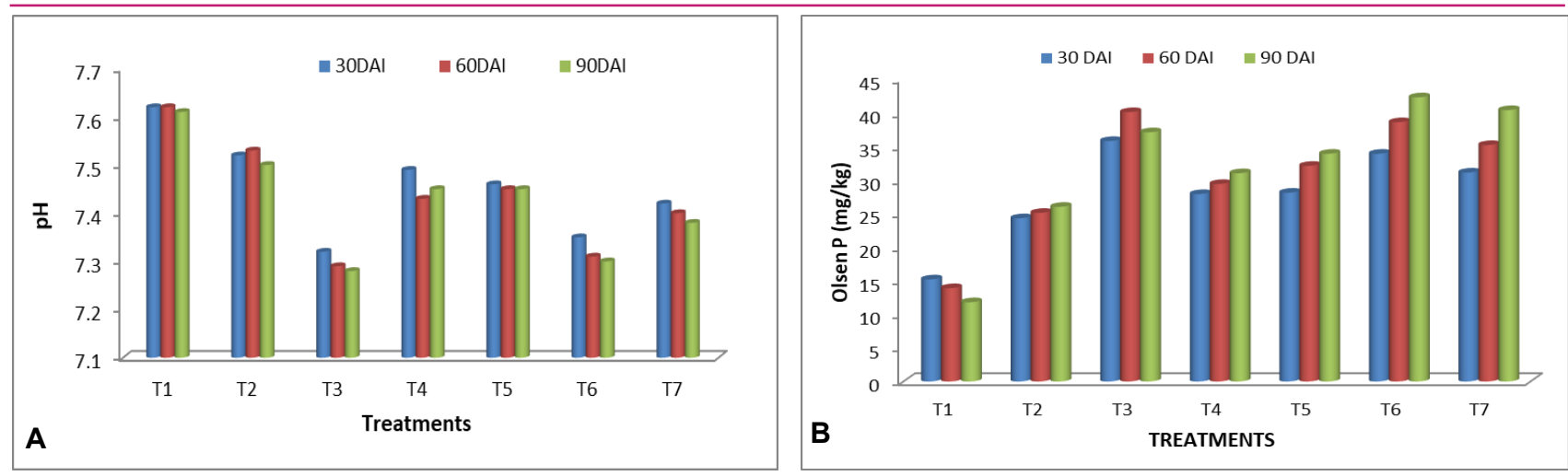

Fig.1. Soil $p H$ and Olsen $P$ at 30, 60 and90 DAl (Incubation Experiment) (A) Soil $p H$ (B) Olsen $P$.
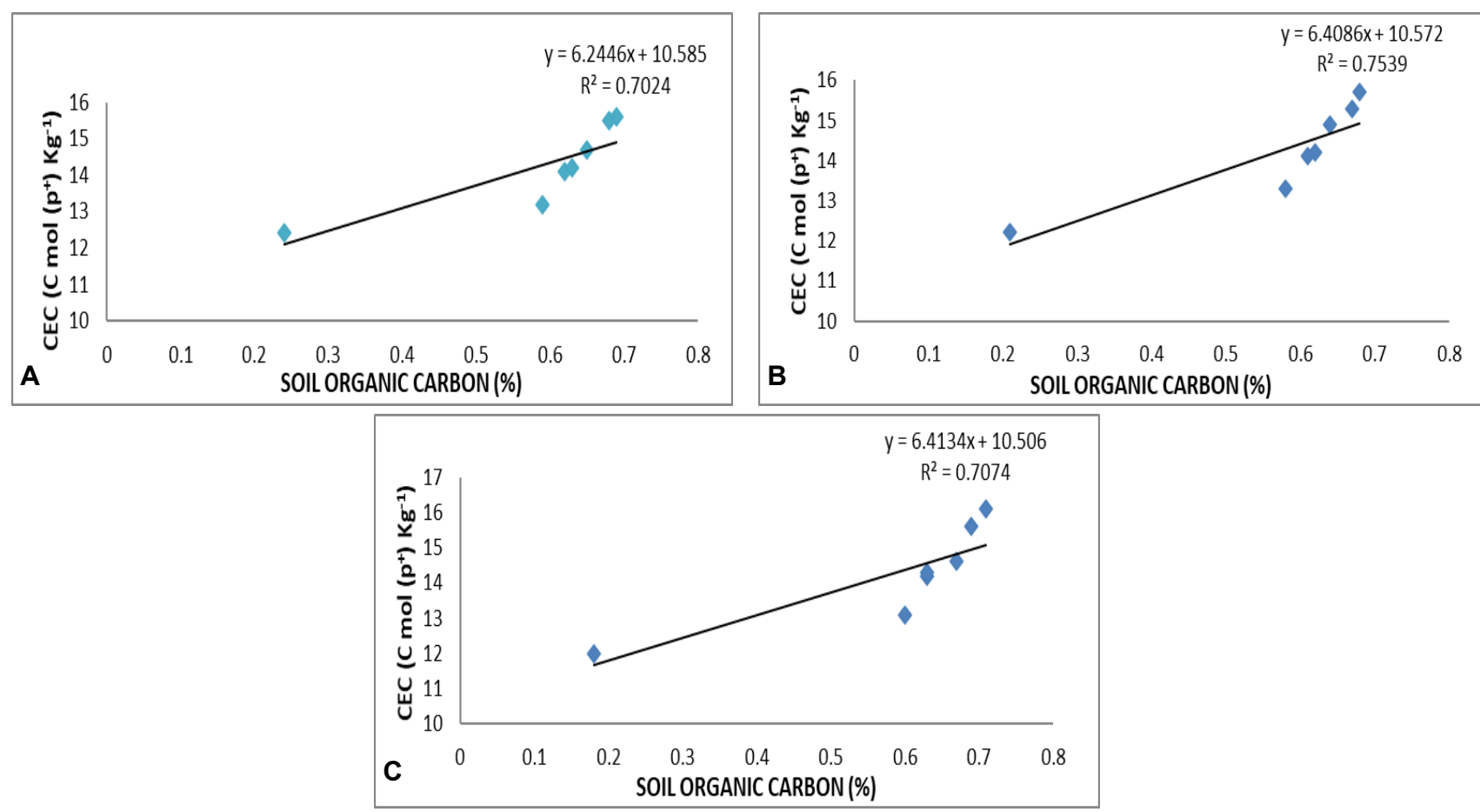

Fig. 2. Relationship between CEC and SOC 130 DAI (B) 60 DAI (C) 90 DAI.

ment. Available $P$ significantly $(p=0.05)$ increased with the application of SSP or Nano P along with PSB. The increased $P$ may have been improved due to the more solubilizing effect of PSB in the soil. This finding has useful implications for $P$ fertilizer management to reduce applied $P$ fixation and increased availability of $P$ in soil solution. However, the results proved that application of phosphocompost (water hyacinth based) with PSB significantly $(p=0.05)$ influenced the soil microbial population, $\mathrm{pH}, \mathrm{EC}, \mathrm{CEC}$, and SOC than other $\mathrm{P}$ sources applied; also, it recorded higher $\mathrm{p}$ availability next to SSP and Nano P application. Water hyacinthbased phosphocompost has an added advantage as it is a no-cost organic manure except collection and $P$ enriching material cost. Being not only a cheapest composting source for $\mathrm{P}$ but also helps in environmental pollution management and it paves a new way to input cost cutting on $P$ fertilizers.

\section{ACKNOWLEDGEMENTS}

The authors acknowledge the Department of Soil Science and Agricultural Chemistry, Faculty of Agriculture, Annamalai University, Annamalai Nagar for providing research facilities cum support for the conduct of the experiment.

\section{Conflict of interest}

The authors declare that they have no conflict of interest.

\section{REFERENCES}

1. Aditya Kumar, Sanjay Kumar Shahi, Abhinandan Singh \& Chandrashekhar (2018). Effect of integrated use of NPKZn, FYM and bio- fertilizers on soil properties and performance of rice crop (Oryza sativa L.) J. Pharmacogn Phytochem., 7(2), 3876-3880. 
2. Alamgir, M., Kibria, M.G.\& Islam, M. (2011) Effects of farm yard manure on cadmium and lead accumulation in Amaranth (Amaranthus oleracea L.). J. Soil Sci. Environ. Manag.,2 (8), 237-240.

3. Amitava Rakshit, Sarkar, N.C. \& Debashish Sen. (2008). Influence of organic manures on productivity of two varieties of rice. J. Central Euro. Agri., 9(4), 629-634.

4. Bhat, N. A., Riar A., Ramesh,A., Iqbal, S., Sharma, M. P., Sharma, S. K. \& Bhullar, G. S. (2017). Soil Biological Activity Contributing to Phosphorus Availability in Vertisols under Long-Term Organic and Conventional Agricultural Management. Front. Plant Sci., 8:1523. doi: 10.3389/ fpls.2017.01523

5. Chesti, M.H., Kohli, A., Mujtaba, A., Sofi, J.A., Nazir, Q. \& Tabasum, P. (2015) Effect of integrated application of inorganic and organic sources on soil properties, yield and nutrient uptake by rice (Oryza sativa L.) in Intermediate Zone of Jammu and Kashmir. J. Ind. Soc. Soil Sci.,63(1), 88-92.

6. Dey, P., Santhi, R., Maragatham, S. \& Chellamuthu,K.M. (2017). Status of phosphorus and potassium in the Indian soils vis-a vis world soils. Indian Journal of Fertilizers., 13 (4),44-59.

7. Dushyant Pandey, Shrikant chitale \& Thakur, D.S. (2015) Nutrient Uptake and Physico: Chemical Properties of Soil Influenced by Organic and Inorganic Packages in Rice. Curr. Agric. Res. J., 3(1),80-84.

8. FAI (2016). Retrieved from https://www.faidelhi.org/genera I/Annual_Report,_2016-17.pdf.

9. Fazli Wahid, Muhammad Sharif, Siegrid Steinkellner Azim Khan, M., Marwat, K.B., \& Khan, S.A. (2016). Inoculation of arbuscular mycorrhizal fungi and phosphate solubilizing bacteria in the presence of rock phosphate improves phosphorus uptake and growth of maize. Pak. J. Bot., 48(2), 739-747.

10. Hazalton, P. \& Murphy, B. (2007). Evaluation of soil quality in relation to landuse effect in Akamkpa, cross river state- Nigeria. Apll. Ecol. Environ. Sciences., 5(2),35-42.

11. India Stat. (2018). State of Indian Agriculture 2017-18. www.indiastat.com.

12. Kang, G. S., Beri, V., Sidhu, B. S. \& Rupela, O. P. (2005) $A$ new index to assess soil quality and sustainability of wheat-based cropping systems. Biol. Fertil. Soils.,(41) 389 $-398$.

13. Kannan N., Rangaraj S., Gopalu, K., Rathinam, Y., \& Venkatachalam, R. (2012). Application of silica nanoparticles in maize to enhance fungal resistance. Curr. Nanosci., 8, 902-908.

14. Kannan, R., Lalith, Dhivya, M., Abinaya, D., Krishna, Lekshmi, R., \& Krishnakumar, S. (2013). Effect of Integrated Nutrient Management on Soil Fertility and Productivity in Maize. Bulletin of Environment, Pharmacol. Life Sci.,2 (8), 61-67.

15. Katkar R.N., Sonune, B.A., \& Kadu, P.R. (2011). Longterm effect of fertilization on soil chemical and biological characteristics and productivity under sorghum (Sorghum bicolor) wheat (Triticum aestivum) system in Vertisol.
Indian J. Agri. Sci., 81(8),734-739.

16. Mandal, A., Purukayastha, T.J., \& Patra, A.K. (2014). Phytoextraction of arsenic contaminated soil by Chinese break fern (Pteris vittata): effect on soil miocrobiological activities. Biol. Fertil Soil., 50,1247-1252.

17. Mandal, N. (2014). Development of biodegradable nanoclay polymer composites (NCPC) for controlled delivery of $\mathrm{Zn}$ for wheat and rice rhizosphere. Ph.D Thesis, PG School, IARI, New Delhi-110012.

18. Marschner, P., Ellen Kandeler \& Bernd Marschner (2003). Structure and function of the soil microbial community in a long-term fertilizer experiment. Soil Biol. Biochem.,35: 453 $-461$.

19. Pandey, M.P., Verulkar, S.B., \& Sharma, D. (2010). Rice research: past achievements, present scenario and future thrust. Indian J. Agric. Sci., 80(6),447-69.

20. Panhwar, Q.A., \& Othman, R. (2011).Contribution of phosphate-solubilizing bacteria in phosphorus bioavailability and growth enhancement of aerobic rice. Span. J. Agric. Res., 9(3),810-820.

21. Panhwar,Q.A., Radziah, O., Naher, U.A., \& Shamshuddin, J.(2013). Effect of phosphate-solubilizing bacteria and organic acid on $\mathrm{P}$ solubilization from phosphate rock in aerobic rice. Sustain. World J., doi:10.1155/2013/272409.

22. Pramer, D., Schmidt, E. L. (1965) . Experimental soil microbiology. Burgess Publ. Co., Minneapolis.

23. Selva Preetha, P., \& Balakrishnan, N. (2017). A Review of Nano Fertilizers and Their Use and Functions in Soil. Int. J. Curr. Microbiol. App. Sci., 6(12), 3117-3133.

24. Sharmila Rahale (2011). Nutrient release pattern of nano fertilizer formulation. Ph.D (Agri.) Thesis. Tamilnadu Agricultural University, Coimbatore.

25. Singh M.D., C. Gautam, O.P. Patidar, H.M. Meena, G.Prakasha \& Vishwajith. (2017). Nano-Fertilizers is a new way to increase nutrients use efficiency in crop production. Intl. J. Agri. Sci., 9(7),3831-3833.

26. Tarafdar, J.C., Xiang, Y., Wang, W.N., Dong, Q. \& Biswas, P. (2012c). Standardization of size, shape and concentration of nanoparticle for plant application. Appl. Biol. Res., 14, 138-144.

27. Thakur, A.K., Rath, S. \& Kumar, A. (2011). Performance evaluation of rice varieties under system of rice intensification compared with the conventional transplanting system. Archieves of Agron. Soil Sci., 57(3),223-238.

28. Wei L.L., Chen, C. R. \& Xu, Z. H. (2010). Citric acid enhances the mobilization of organic phosphorus in subtropical and tropical forest soils. Biol. Fertil. Soils.,46,765-769.

29. Yan, X., Wei, Z., Hong, Q., Lu, Z. \& Wu, J. (2017).Phosphorus fractions and sorption characteristics in a subtropical paddy soil as influenced by fertilizer sources. Geoderma, 295, 80-85.

30. Zhao, I.M., Wu, L.H., Li, Y.S., Animesh, S., Zhu, D.F. \& Uphoff, N. (2010).Comparison of yield, water use efficiency and soil microbial biomass as affected by the system of rice intensification. Commun. Soil Sci. Plant Analysis. 41, $1-12$. 